\title{
Effects of Drought Stress on Yield and Yield Attributing Characters of Wheat: A Review
}

\author{
Ankita Khatiwada*, Ichchha Neupane, Bikash Sharma, Niku Bhetwal, Benif Pandey
}

${ }^{1}$ Paklihawa Campus, Institute of Agriculture and Animal Science,Tribhuwan University, Rupandehi, Nepal

*Author for Correspondence: Email-khatiwadapramangana2904@gmail.com

\begin{abstract}
With the change in climate patterns, the world is encountering the threat of drought. Since major wheat-producing countries are situated in drier parts of the world anddepend on monsoon rain for wheat cultivation so drought is becoming a serious drawbackfor wheat production.In this review, previous works were assessed to explore the effects of drought stress on yield and yield-attributing characters of wheat. The plant modifies its physio-chemical processes in response to moisture deficiencyso the yield attributing characters like plant height, spike length, no. of spikes per unit area, no. of spikelets/spike, no. of grains/spike, biomass yield, harvest index, test weight, etc. are affected ultimately reducing the grain yield. The extent of loss of yield differs among genotypes and the developmental stages of the crop and is characterized by various soil, plant, andenvironmental factors. Owing to the alliance of yield with the genetic make-up of the crop, drought stress, and its effect are not the concern of only agronomists but rather also of plant breeders. Wheat is the backbone of various food-based and feed-based industries so the enhancement in the production of wheat is a must for the sustainability of the growing population. The article exclusively focuses on the hazards of drought on yield and yield- attributing factors as it is the major concern of many present-day breeders as well as world leaders.
\end{abstract}

Keywords: Drought, yield, yield components, wheat

\section{Introduction}

Wheat is the principal cereal crops cultivated in the world and consists of $1 / 5$ th part of the entire human food calories (Ali et al.2012; Muhammad Farooq et al, 2014; Hawkesford et el, 2013) whereas, in Nepal, wheat is the second most human-consumed food grain after rice and follows rice and maize ranking third in overall consumption (Khatri et al., 2017). According to Ben-ari \& Makowski, 2014, wheat production is more distributed than rice and soybean. Wheat is thought to have been domesticated from about 11,000 and 9500 years before(Lev-Yadun et al., 2000; Wang et al., 2017). Derived from South Western Asia(Ali et al., 2012) and extended to major parts of the world, it contributes $30 \%$ to the food crops in the world and is taken as the staple food by more than 10billion people so it is listed as a first cereal crop in the global context(Ali et al., 2012).The wheat has wide use in making bread, cookies, crumpets, flake, flour, people also prefer to consume wheat grain as roasted grain and it is of great importance to feed the livestock due to high nutritional value(Pandey et al., 2020). The wheat production in the world is estimated to be 760.1million tonnes(FAO, 2020).
Thedeveloped nations have a $14 \%$ increased yield of wheat than the developing onesdue to irrigation provided to wheat. (Shiferaw et al., 2013).AccordingtoMIRCA (2000), the total percentage of land irrigated under wheat isonly 31.1\%(Portmann et al., 2010).

Drought stress is the major abiotic cause for the yield reduction(Budak et al., 2013; Tabassam et al., 2014) in wheat as it is grown under rain-fed conditions inarid and semi-arid regions in major parts of the world(Boyer, 1982). By 2025, around 1.8 billion people are likely to encounter an absolute water shortage, and about $65 \%$ of the world population have to survive in water stress environment(Nezhadahmadi et al., 2013). About 32\% of wheat is exposed to different types of drought stress during its growth period in developing countries(Keyvan, 2010). Drought stress creates detrimental effects in plants as plants adopt new physio-chemical processes to overcome the stress. The morphology, physiology, biochemistry, and growth of the plants are altered by the drought stress which ultimately causes yield loss. The primary effect of drought is weakened germination which results in the wretched crop stand establishment(Kaya et al., 2006). The 
stress, at different developmental stages, can decrease cell expansion and division, alter the opening and closing of stomata, pigment formation, water, and nutrient uptake, protein structure, antioxidant production, hormone composition, cuticle thickness, chlorophyll content, etc. adversely affecting the yield components i.e. plant height, number of plants per unit area, number of spikes per plant and no. of grains per spikes per plant.(Mehraban et al., 2019; Nezhadahmadi et al., 2013). Wheat during grain filling, when exposed to drought stress darts leaf senescence (Habuš Jercic et al., 2018; Yang et al., 2003), decrease grain filling period and hence reduces the mean weight of the grains due to remobilization of photoassimilates, nitrogen stored before anthesis(M. Farooq et al., 2009; Giunta et al., 1993; Waraich et al., 2007), and shortened life cycle. The yield and yield-related traits are affected by drought stress due to pollen abortion, reduced food reserves and development of sterile tillers(Qaseem et al., 2019) and reduced shoot biomass(Ashraf \& Khan, 1993).

The article focuses on the impacts of drought stress on the yield and yield components of the wheat. Believing that it will help to understand the graveness of the problem, we have tried to entitle the causes of the bleak outcome of yield and yield-related traits. In today's context when the population is rising geometrically; if the crop yield decreases due to climatic factors the hungry population will rise hence the paper outlines some aspects of drought stress on yield-related trait so the energies would be focused on increasing the yield of the wheat from the present land rather than increasing the land under wheat.

\section{Methodology}

The latest research papers and review papers suitable for studying effects of drought stress on yield and yield-components of wheat were collected through various national and international journals. Also, the statistical data were collected from international organizations like FAO for more accurate information. All the findings present in this paper are secondary information extracted from above-mentioned sources.

\section{Effects of Drought on Yield and Yield-attributing Traits}

Yield is the measurement of product harvested per unit area, generally measured in terms of tons/hectare. The characters or traits of the plants that contribute to the yield of the concerned plant are known as yield-attributing traits of plant. In the context of wheat, plant height, spike length, no. of spikes per unit area, no. of spikelets per spike, no. of grains per spike, biomass yield, harvest index, and test weight are said to be the characters that influence the yield of wheat. The yield attributing traits are inter-related with each other and with the yield hence any variation in the above- mentioned traits causes changes in the yield of wheat.

\section{Plant Height}

Drought stress negatively affects plant height of all wheat irrespective of species or cultivars (Kilic and Yagbasanlar, 2010) but the severity is highest in terminal drought followed by tillering drought, pre-flowering drought, and post-flowering drought (Mirbahar et al., 2009; Saleem, 2003). The height of wheat is significantly affected if exposed to drought stress from one-leaf stage to the floral initiation stage which results in the low accumulation of dry matter and finally reduced plant production (Moayedi et al, 2010). The protoplasm is dehydrated and loses its turgidity during a drought so cell elongation, expansion, and mitosis is effected and also the plant sheds its leaves to prevent moisture loss ultimately diminishing the height of the plant(Ghulam et al., 1999; Hussain et al., 2008; Khakwani et al., 2012; Nonami, 1998)

\section{Spike Length}

Spike length, though vaguely affected by drought stress as compared to other yield attributing characters (Kiliç \& Ya?basanlar, 2010), it is reduced in all wheat cultivars to some extent depending on the time of application of drought(Saleem, 2003). The lack of moisture regime before flowering causes severe decrement of spike length. The effect of drought on spike length is more pronounced after the 6th week of emergence rather after immediately sown(F. Nawaz et al., 2012). The spike length responds most adversely to the terminal drought followed bydrought after thetillering stage, pre-flowering drought and finally post-flowering drought(Mirbahar et al., 2009).

\section{No. of Spikes Per Unit Area}

The no. of spikes is one of the major yield componentsaffecting the grain yield which is affected by drought stress(Kiliç \& Ya?basanlar, 2010). The depressed soil water potential value during stem elongation or degraded survivability of tillers during grain filling is regarded as the cause of the decreased no. of spikes per unit area(Giunta et al., 1993). The utmost seriousness by drought stress is witnessed during the anthesis stage whereas the drought implied before or after anthesis does not cause graveness as at the anthesis stage(Guttieri et al., 2001; Khan \& Naqvi, 2011; Moayedi et al., 2010; Saeidi \& Abdoli, 2015) as the potentials of spikes are formed before spike initiation stage (Araus et al., 2002). 


\section{No. of Spikelets/spike}

The number of spikelets per spike is one of the chief factors determining the total yield of the plant and it is highly affected by drought(F. Nawaz et al., 2012). When Qaseem et al. (2019) exposed bread wheat to drought stress before anthesis, the spikelets per spike wasgreatly reduced which was also noted by Mirbahar et al., (2009) as he obtained less no. of spikelets per spike from the field of pre-flowering drought than the post-flowering drought. Also, Moustafa et al., (1996) concluded that drought stress at the tillering stage causes less effect to the no. of spikelets per spike than at the heading stage. According to Ghulam et al., 1999 drought stress, either at vegetative or at the reproductive phase show an equal silencing effect on spikelet no. per spike. The drought stress also increases infertile spikelets per spike in wheat(Akram et al., 2004; Den?i'den?i'c et al., 2000).

\section{No. of Grains/spike}

The no. of grains per spike in wheat under drought stress is surpassed by the irrigated wheat(Giunta et al., 1993; Kiliç \& Ya?basanlar, 2010).Ehdaie et al. (1988) noted that among all the yield components, no. of grains per spike was most intensely affected which was in accordance with Fischer \& Maurer (1978), Guttieri et al.(2001) and Zhang et al. (2006). The relative water content of the plant is positively and significantly related to the no. of grains per spike so the cultivar with high RWC has higher tolerance in drought and reduction in grain no. is low. Hence, the no. of grains in a spike is differently reduced in different cultivars(Khakwani et al., 2012). Though the extent of reduction is different, all types of wheat show the reduction in no. of grains per spike if exposed to drought stress(Saleem, 2003). The terminal drought affects the no. of grains held by a spike, the most thereafter the pre-flowering drought and post-flowering drought(Mirbahar et al., 2009; Moayedi et al., 2010; Qaseem et al., 2019).The potentials of spike and no. of spikes per grain is formed before spike initiation(Araus et al., 2002) so drought applied at the heading stage causes significant variation in no. of grains per spike than at the tillering stage (Abid et al., 2018; Moustafa et al., 1996)and no effect after anthesis(Plaut et al., 2004).The lack of fertilization of egg which causes underdeveloped ovule is often credited with the reduced grain number. The drought stress during the pollen development phase produces sterile pollen so the fertilization is disturbed(Manjarrez-Sandoval et al., 1989).

\section{Grain Yield}

The yield components like plant height, spike length, effective tillers/m2, no. of grains/spike shows a linear relationship with grain yield and hence yield is the most affected factor by drought(Kiliç \& Ya?basanlar, 2010; F. Nawaz et al., 2012; Qaseem et al., 2019; Sutton \& Dubbelde, 1980; Thompson \& Chase, 1992). The taller plant has deeper root penetration so there is the optimal utilization of water and more stored assimilates, both of which lacks during a drought so the yield is reduced(Amiri et al., 2013). The grain yield of all the wheat genotypesdecrease despite the superiority of the genotypes if exposed to drought(Nouri et al., 2011; Öztürk \& Korkut, 2018; Saleem, 2003) but the cultivars are less affected than the landraces obtained from different countries(Den?i'den?i'c et al., 2000).The drought causes more relative decrement in grain weight than the no. of grains and hence the pronounced reduction in the yield of the wheat under drought stress is because of reduced weight of grain rather than less no. of grains(Giunta et al., 1993). Thedrought applied after the anthesis period causes less reduction in wheat yield than the drought at anthesis and graining(Muhammad Farooq et al., 2014; A. Nawaz et al., 2013; F. Nawaz et al., 2012) because of decreased carbon fixation and assimilate translocation(Asada, 2006), decreased grain set and grain filling(A Ahmadi \& Baker, 2001; A. Nawaz et al., 2013). The leaf senescence is quickened in the absence of a significant amount of water(Senapati et al., 2019) so the scarcity of water interrupts leaf gas exchange processes which causes the limitation of the size of the source and sink tissues ultimately hampering translocation of assimilates(Anjum et al., 2011; M. Farooq et al., 2009; Jaleel et al., 2009). Grain yield is more affected by water used during anthesis than the total amount of water(Den?i'den?i'c et al., 2000; Passioura, 1977). The cutback in the grain yield because of drought stress after the anthesis phase is due to the reduction in photo-assimilates production, the ability of the sink to absorb photoassimilates, and grain filling duration. Since the initial grain growth and development phases are least affected under the post-anthesis drought, the reduction of grain yield during this phase reveal that a low amount of photo-assimilates are supplied for grain filling(Ali Ahmadi \& Siosemardeh, 2005; Bahman Ehdaie et al., 2006; Saeidi \& Abdoli, 2015). And, the contraction on yield is profound when stress is applied at the heading stage than at tillering(Moustafa et al., 1996). The drought stress interferes with the growth and photosynthesis processes of the plants which are regarded as the major cause of reduced grain yield(Almeselmani et al., 2011). 


\section{Biomass Yield}

The inclination of biomass indicates the increment in photosynthetic organs above the ground, stem and yield components that causes increased yield but the leaf expansion and leaf development are hampered by the water deficit(Anjum et al., 2011)so the biomass yield is reduced by drought stress(Alexieva et al., 2001; Taheri et al., 2011). The decrement in grain yield followed by plant height is regarded as the principal cause of biomass reduction in wheat(J. Zhang et al., 2018). Although the biomass yield reduction is different between irrigated and stressed fields, it is not even among the genotypes of the same field(Saleem, 2003). The biomass production is directly proportional to the photosynthesis but the leaf senescence is hastened in lack of water (Senapati et al., 2019)and also, the assimilates production is lower under drought and hence are either absorbed or stored by the source (Abdoli \& Saeidi, 2013), so the biomass yield is reduced under drought stress.

\section{Harvest Index}

Harvest index is the ratio of grain yield to biological yield which determines the capacity of plants to translocate physiological matters to grains(Moayedi et al., 2010) so the harvest index is substantially affected by the stressed conditions(Giunta et al., 1993; Qaseem et al., 2019).The harvest index shares a positive relationship with grain yield and negative with total biomass. The economic yield of wheat is reduced during stress conditionsso the harvest index is reduced when wheat is exposed to drought. The sink size decreases under the stress treatment so the demand for assimilates is reduced causing retention of assimilates in the vegetative organ so the harvest index of wheat under drought stress declines(Giunta et al., 1993).

\section{Test Weight}

The test weight is differently affected by drought at different phenological stages; most adversely at drought after tillering, then before flowering, and least by drought after flowering(Akram et al., 2004; Mirbahar et al., 2009; Moayedi et al., 2010; F. Nawaz et al., 2012).The 1000 grain weight is the united effect of length of the spike, fertile spikelet number, grain weight per spike and number of grain(B. Zhang et al., 2006). The negative relationship is found between 1000-grain weight and no. of grains per spike i.e. reduced no. of grains per spike under drought means increased grain weight so the minimum reduction is found in the mean values of 1000 grain weight as compared to other yield components. This may be due to the distribution of the accessible assimilates to fewer amount of seeds resulting in improved grain filling (B. Ehdaie et al., 1988; Ghulam et al., 1999; Giunta et al., 1993; Moral et al., 2003). But, sometimes the nutrient uptake efficiency and translocation of photosynthatesmight be disturbed resulting in the production of shrunken grain because of accelerated maturity forced by stress causing a significant decline in 1000 grain weight of wheat(Khakwani et al., 2012).

\section{Conclusion}

Drought is the most serious, yet a most common problem to the global wheat producers and the ongoing climate change is adding fuel to it. Drought stress affects plant height, plant biomass, no. of spikes, no. of spikelets, and ultimately grain yield. Though all the yield components of all wheat genotypes are negatively affected under drought, the intensity of effect varies. The extent of the effect of drought stress on crops relies mostly on parameters such as; phenological stage of crop, intensiveness, and time period of drought stress. The response of wheat to drought stress may also be affected by morphological traits of the plant such as; effective no. of fertile tillers/plant, no. of spikes $/ \mathrm{m} 2$, no. of spikelets/spike, no. of grains/spike, test weight, spike length, spike weight, and biomass. The crop yield is extremely diminished when drought occurs in the heading or flowering stage. The response of the plant to drought also differs based on the distribution of rainfall, evaporative demands, and moisture storing capacity of soil.Following the water shortage plant responds physiologically to adjust the environment causing the closure of stomata, decreased photosynthesis, low distribution of photo-assimilates so the yield and yield-components of wheat are reduced ultimately by drought stress.

The crop embraces physio-chemical and/or phenological changes to surpass the drought period. The wheat should be well irrigated during the water-sensitive phenological stages. The extent of effects of drought in yield and yield-components of wheat is well known but the agro-morphological changes are the result of physio-chemical modifications on the molecular level. The ground level changes in a plant cell that harms yield and yield-attributes should be identified to cure the effects of drought from the root. 


\section{Acknowledgement}

We would like to express our special thanks to Asst. Prof. Mukti Ram Poudel, for his guidance and constructive feedback.

\section{References}

Abdoli, M., \& Saeidi, M. (2013). Evaluation of water deficiency at the post anthesis and source limitation during grain filling on grain yield, yield formation, some morphological and phonological traits and gas exchange of bread wheat cultivar. Albanian Journal of Agricultural Sciences, 12(2), 255-265.

Abid, M., Ali, S., Qi, L. K., Zahoor, R., Tian, Z., Jiang, D., Snider, J. L., \& Dai, T. (2018). Physiological and biochemical changes during drought and recovery periods at tillering and jointing stages in wheat (Triticum aestivum L.). Scientific Reports, 8. https://doi.org/10.1038/s41598-018-21441-7

Ahmadi, A, \& Baker, D. A. (2001). The effect of water stress on the activities of key regulatory enzymes of the sucrose to starch pathway in wheat. In Plant Growth Regulation (Vol. 35). https://doi.org/10.1023/A1013827600528

Ahmadi, Ali, \& Siosemardeh, A. (2005). Investigation on the Physiological Basis of Grain Yield and Drought Resistance in Wheat: Leaf Photosynthetic Rate, Stomatal Conductance, and Non-stomatal Limitations. International Journal of Agriculture and Biology, 7(5), 807-811.

Akram, H. M., Iqbal, M. S., Saeed, M., Yar, A., Ali, A., Sahi, K. A., \& Nadeem, M. A. (2004). Drought Tolerance Studies of Wheat Genotypes. Pakistan Journal of Biological Sciences, 7(1), 90-92. https://doi.org/10.3923/pjbs.2004.90.92

Alexieva, V., Sergiev, I., Mapelli, S., \& Karanov, E. (2001). The effect of drought and ultraviolet radiation on growth and stress markers in pea and wheat. Plant, Cell and Environment, 24(12), 1337-1344. https://doi.org/10.1046/j.1365-3040.2001.00778.x

Ali, A., Khaliq, T., Ahmad, A., \& Ahmad, S. (2012). How wheat responses to nitrogen in the field? A review. Crop and Environment, 3(1-2), 71-76.

Almeselmani, M., Abdullah, F., Hareri, F., Naaesan, M., Adel Ammar, M., ZuherKanbar, O., \& Alrzak Saud, A. (2011). Effect of Drought on Different Physiological Characters and Yield Component in Different Varieties of Syrian Durum Wheat. Journal of Agricultural Science, 3(3). https://doi.org/10.5539/jas.v3n3p127

Amiri, R., Bahraminejad, S., \& Jalali-honarmand, S. (2013). Effect of terminal drought stress on grain yield and some morphological traits in 80 bread wheat genotypes. International Journal of Agriculture and Crop Sciences, 5(10), 1145-1153.

Anjum, S. A., Xie, X. yu, Wang, L. chang, Saleem, M. F., Man, C., \& Lei, W. (2011). Morphological, physiological and biochemical responses of plants to drought stress. African Journal of Agricultural Research, 6(9), 2026-2032. https://doi.org/10.5897/AJAR10.027

Araus, J. L., Slafer, G. A., Reynolds, M. P., \& Royo, C. (2002). Plant breeding and drought in C3 cereals: What should we breed for? Annals of Botany, 89, 925-940. https://doi.org/10.1093/aob/mcf049

Asada, K. (2006). Production and scavenging of reactive oxygen species in chloroplasts and their functions. Plant Physiology, 141(2), 391-396. https://doi.org/10.1104/pp.106.082040

Ashraf, M. Y., \& Khan, A. H. (1993). Effect of Drought Stress on wheat plant in early stage. Pakistan Journal of Agricultural Research, 14(2), 261-269.

Ben-ari, T., \& Makowski, D. (2014). Decomposing global crop yield variability. Environmental Research Letters, 9. https://doi.org/10.1088/1748-9326/9/11/114011

Boyer, J. S. (1982). Plant Productivity and Environment. Science, 218(4571), 443-448. https://doi.org/0.1126/science.218.4571.443

Budak, H., Kantar, M., \& Kurtoglu, K. Y. (2013). Drought Tolerance in Modern and Wild Wheat. The Scientific World Journal. https://doi.org/10.1155/2013/548246

Deni'deni'c, S., Kastori, R., Kobiljski, B., \& Duggan, \& B. (2000). Evaluation of grain yield and its components in wheat cultivars and landraces under near optimal and drought conditions. Euphytica, 113, 43-52. https://doi.org/10.1023/A:1003997700865

Ehdaie, B., Waines, J. G., \& Hall, A. E. (1988). Differential Responses of Landrace and Improved Spring Wheat Genotypes to Stress Environments. Crop Science, 28(5), 838-842. https://doi.org/10.2135/cropsci1988.0011183x $002800050024 \mathrm{x}$

Ehdaie, Bahman, Alloush, G. A., Madore, M. A., \& Waines, J. G. (2006). Genotypic variation for stem reserves and mobilization in wheat: II. Postanthesis changes in internode water-soluble carbohydrates. Crop Science, 46(2), 2093-2103. https://doi.org/10.2135/cropsci2006.01.0013

FAO. (2020). Cereal_supply_and_demand_data_may. http://www.fao.org/fileadmin/templates/worldfood/Report s_and_docs/Cereal_supply_and_demand_data_may.xls

Farooq, M., Wahid, A., Kobayashi, N., Fujita, D., \& Basra, S. M. A. (2009). Review article Plant drought stress?: e ff ects, mechanisms and management. Agronomy for Sustainable Development, 29, 185-212. https://doi.org/10.1051/agro:2008021

Farooq, Muhammad, Hussain, M., \& Siddique, K. H. M. (2014). Drought Stress in Wheat during Flowering and Grain-filling Periods. Critical Reviews in Plant Sciences, 33(4), 331-349. https://doi.org/10.1080/07352689.2014.875291

Fischer, R. A., \& Maurer, R. (1978). Drought resistance in spring wheat cultivars. I. Grain yield responses. Australian Journal of Agricultural Research, 29(5), 897-912. https://doi.org/10.1071/AR9780897 
Ghulam, Q., Muhammad, S., \& Cheema, M. A. (1999). Effect of Water Stress on Growth and Yield Performance of Four Wheat Cultivars. Pakistan Journal of Biological Sciences, 2(1), 236-239.

Giunta, F., Motzo, R., \& Deidda, M. (1993). Effect of drought on yield and yield components of durum wheat and triticale in a Mediterranean environment. Field Crops Research, 33(4), 399-409. https://doi.org/10.1016/0378-4290(93)90161-F

Guttieri, M. J., Stark, J. C., Brien, K. O., \& Souza, E. (2001). Relative Sensitivity of Spring Wheat Grain Yield and Quality Parameters to Moisture Deficit. Crop Science, 41 , $335-344$ https://doi.org/10.2135/cropsci2001.412327x

Habuš Jer?i?, I., Bari?, M., Kereša, S., Bošnjak Mihovilovi?, A., Poljak, M., \& Lazarevi?, B. (2018). Effect of terminal drought on yield and some physiological traits of winter wheat. Genetika, 50(2), 747-753. https://doi.org/10.2298/GENSR1802747H

Hussain, M., Malik, M. A., Farooq, M., Ashraf, M. Y., \& Cheema, M. A. (2008). Improving drought tolerance by exogenous application of glycinebetaine and salicylic acid in sunflower. Journal of Agronomy and Crop Science, 194(3),

193-199. https://doi.org/10.1111/j.1439-037X.2008.00305.x

Jaleel, C. A., Manivannan, P., Wahid, A., Farooq, M., Juburi, H. J. A., Somasundaram, R., \& Panneerselvam, R. (2009). Drought stress in plants: A review on Morphological Characteristics and Pigment Composition. International Journal of Agriculture and Biology, 11(1), 100-105.

Kaya, M. D., Okçu, G., Atak, M., Çikili, Y., \& Kolsarici, Ö. (2006). Seed treatments to overcome salt and drought stress during germination in sunflower (Helianthus annuus L.). European Journal of Agronomy, 24(4), 291-295. https://doi.org/10.1016/j.eja.2005.08.001

Keyvan, S. (2010). The effects of drought stress on yield, relative water content, proline, soluble carbohydrates and chlorophyll of bread wheat cultivars. Journal of Animal \& Plant Sciences, 8(3), 1051-1060.

Khakwani, A. A., Dennett, M. D., Munir, M., \& Abid, M. (2012). Growth and yield response of wheat varieties to water stress at booting and anthesis stages of development. Pakistan Journal of Botany, 44(3), 879-886.

Khan, N., \& Naqvi, F. N. (2011). Effect of water stress in bread wheat hexaploids. Current Research Journal of Biological Sciences, 3(5), 487-498.

Khatri, H. B., Bhattarai, K., Gyawali, B., Pandey, G., Yadav, L., Tiwari, A., Basnet, S., Rawal, N., \& Khatri, N. (2017). Analysis of Yield Attributing Characters of Different Genotypes of Wheat in Rupandehi, Nepal. International Journal of Environment, Agriculture and Biotechnology (IJEAB), 2(5), 2374-2379 https://doi.org/10.22161/ijeab/2.5.13
Kiliç, H., \& Ya?basanlar, T. (2010). The efect of drought stress on grain yield, yield components and some quality traits of durum wheat (Triticum turgidum ssp. durum) cultivars. Notulae Botanicae Horti Agrobotanici Cluj-Napoca, 38(1), 164-170. https://doi.org/10.15835/nbha3814274

Lev-Yadun, S., Gopher, A., \& Abbo, S. (2000). The cradle of agriculture. Science, 288(5471), 1602-1603. https://doi.org/10.1126/science.288.5471.1602

Manjarrez-Sandoval, P., Gonzalez-Hernandez, V. A., Mendoza-Onofre, L. E., \& Engleman, E. M. (1989). Drought Stress Effects on the Grain Yield and Panicle Development of Sorghum. Canadian Journal of Plant Science, 69, 631-641. https://doi.org/10.4141/cjps89-079

Mehraban, A., Tobe, A., Gholipouri, A., Amiri, E., Ghafari, A., \& Rostaii, M. (2019). The Effects of Drought Stress on Yield, Yield Components, and Yield Stability at Different Growth Stages in Bread Wheat Cultivar (Triticum aestivum L.). Polish Journal of Environmental Studies, 28(2), 739-746. https://doi.org/10.15244/pjoes/85350

Mirbahar, A. ., Markhand, G. S., Mahar, A. R., Abro, S. A., \& Kanhar, N. A. (2009). Effect of water stress on yield and yield components of wheat (TRITICUM AESTIVUM L.) VARIETIES. Iraqi Journal of Agricultural Sciences, 41(3), 1303-1310.

Moayedi, A. A., Boyce, A. N., \& Barakbah, S. S. (2010). The performance of durum and bread wheat genotypes associated with yield and yield component under different water deficit conditions. Australian Journal of Basic and Applied Sciences, 4(1), 106-113.

Moral, L. F. G. del, Rharrabti, Y., Villegas, D., \& Royo, C. (2003). Evaluation of Grain Yield and Its Components in Durum Wheat under Mediterranean Conditions: An Ontogenic Approach. Agronomy Journal, 95, 266-274.

Moustafa, M. A., Boersma, L., \& Kronstad, W. E. (1996). Response of four spring wheat cultivars to drought stress. Crop Science, 36(4), 982-986. https://doi.org/10.2135/cropsci1996.0011183X0036000 40027x

Nawaz, A., Farooq, M., Cheema, S. A., Yasmeen, A., \& Wahid, A. (2013). Stay green character at grain filling ensures resistance against terminal drought in wheat. International Journal of Agriculture and Biology, 15(6), 1272-1276.

Nawaz, F., Ahmad, R., Waraich, E. A., Naeem, M. S., \& Shabbir, R. N. (2012). Nutrient uptake, physiological responses, and yield attributes of wheat (triticum aestivum 1.) exposed to early and late drought stress. Journal of Plant Nutrition, 35(6), 961-974. https://doi.org/10.1080/01904167.2012.663637

Nezhadahmadi, A., Prodhan, Z. H., \& Faruq, G. (2013). Drought tolerance in wheat. The Scientific World Journal, 2013. https://doi.org/10.1155/2013/610721 
Nonami, H. (1998). Plant water relations and control of cell elongation at low water potentials. Journal of Plant Research, 111(3), 373-382. https://doi.org/10.1007/bf02507801

Nouri, A., Etminan, A., Teixeira, J. A., \& Mohammadi, R. (2011). Assessment of yield, yield-related traits and drought tolerance of durum wheat genotypes ( Triticum turjidum var . durum Desf .). Australian Journal of Crop Science, 5(1), 8-16.

Öztürk, ?., \& Korkut, K. Z. (2018). EVALUATION OF DROUGHT TOLERANCE INDICES AND RELATION WITH YIELD IN BREAD WHEAT GENOTYPES UNDER DROUGHT STRESS CONDITIONS. Journal of International Scientific Publications, 6.

Pandey, M., Shrestha, J., Subedi, S., \& Shah, K. K. (2020). Role of Nutrients in Wheat?: a Review. Tropical Agrobiodiversity, 1(1), 18-23. https://doi.org/10.26480/trab.01.2020.18.23

Passioura, J. B. (1977). Grain yield, Harvest index and water use of wheat. The Journal of the Australian Institute of Agricultural Science, 43, 117-120.

Plaut, Z., Butow, B. J., Blumenthal, C. S., \& Wrigley, C. W. (2004). Transport of dry matter into developing wheat kernels and its contribution to grain yield under post-anthesis water deficit and elevated temperature. Field Crops Research, 86(2-3), 185-198. https://doi.org/10.1016/j.fcr.2003.08.005

Portmann, F. T., Siebert, S., \& Döll, P. (2010). MIRCA2000 Global monthly irrigated and rainfed crop areas around the year 2000?: A new high ? resolution data set for agricultural and hydrological modeling. GLOBAL BIOGEOCHEMICAL CYCLES, 24, 1-24. https://doi.org/10.1029/2008GB003435

Qaseem, M. F., Qureshi, R., \& Shaheen, H. (2019). Effects of Pre-Anthesis Drought, Heat and Their Combination on the Growth, Yield and Physiology of diverse Wheat (Triticum aestivum L.) Genotypes Varying in Sensitivity to Heat and drought stress. https://doi.org/10.1038/s41598-019-43477-z

Saeidi, M., \& Abdoli, M. (2015). Effect of drought stress during grain filling on yield and its components, gas exchange variables, and some physiological traits of wheat cultivars. Journal of Agricultural Science and Technology, 17(4), 885-898.

Saleem, M. (2003). Response of Durum and Bread wheat Genotypes to Drought Stress: Biomass and Yield Components. Asian Journal of Plant Sciences, 2(3), 290-293. https://doi.org/10.3923/ajps.2003.290.293

Senapati, N., Stratonovitch, P., Paul, M. J., \& Semenov, M. A. (2019). Drought tolerance during reproductive development is important for increasing wheat yield potential under climate change in Europe. Journal of Experimental Botany, 70(9), 2549-2560. https://doi.org/10.1093/jxb/ery226

Shiferaw, B., Smale, M., Braun, H., Duveiller, E., Reynolds, M., \& Muricho, G. (2013). Crops that feed the world 10 . Past successes and future challenges to the role played by wheat in global food security. Food Security, 5(3), 291-317. https://doi.org/10.1007/s12571-013-0263-y

Sutton, B. G., \& Dubbelde, E. A. (1980). Effects of water deficit on yield of wheat and triticale. Australian Journal of Experimental Agriculture and Animal Husbandry, 20(106), 594-598. https://doi.org/10.1071/EA9800594

Tabassam, M. A. R., Hussain, M., Sami, A., Shabbir, I., Bhutta, M. A. N., Mubusher, M., \& Ahmad, S. (2014). Impact of drought on the growth and yield of wheat. Scientia Agriculturae, 7(1), 11-18. https://doi.org/10.15192/pscp.sa.2014.3.1.1118

Taheri, S., Saba, J., Shekari, F., \& Abdullah, T. L. (2011). Effects of drought stress condition on the yield of spring wheat (Triticum aestivum) lines. African Journal of Biotechnology, 10(80), 18339-18348. https://doi.org/10.5897/AJB11.352

Thompson, J. A., \& Chase, D. L. (1992). Effect of limited irrigation on growth and yield of a semi-dwarf wheat in southern New South Wales. Australian Journal of Experimental Agriculture, 32(6), 725-730. https://doi.org/10.1071/EA9920725

Wang, J. Y., Xiong, Y. C., Li, F. M., Siddique, K. H. M., \& Turner, N. C. (2017). Effects of Drought Stress on Morphophysiological Traits, Biochemical Characteristics, Yield, and Yield Components in Different Ploidy Wheat: A Meta-Analysis. In Advances in Agronomy (1st ed., Vol. 143). Elsevier Inc. https://doi.org/10.1016/bs.agron.2017.01.002

Waraich, E. A., Ahmad, R., Ali, A., \& Ullah, S. (2007). Irrigation and nitrogen effects on grain development and yield in wheat (Triticum aestivum L.). Pakistan Journal of Botany, 39(5), 1663-1672.

Yang, J. C., Zhang, J. H., Wang, Z. Q., Zhu, Q. S., \& Liu, L. J. (2003). Involvement of abscisic acid and cytokinins in the senescence and remobilization of carbon reserves in wheat subjected to water stress during grain filling. Plant, Cell and Environment, 26(10), 1621-1631. https://doi.org/10.1046/j.1365-3040.2003.01081.x

Zhang, B., Li, F. M., Huang, G., Cheng, Z. Y., \& Zhang, Y. (2006). Yield performance of spring wheat improved by regulated deficit irrigation in an arid area. Agricultural Water Management, 28-42. https://doi.org/10.1016/j.agwat.2005.02.007

Zhang, J., Zhang, S., Cheng, M., Jiang, H., Zhang, X., Peng, C., Lu, X., Zhang, M., \& Jin, J. (2018). Effect of Drought on Agronomic Traits of Rice and Wheat: A Meta-Analysis. International Journal of Environmental Research and Public Health, 15(5), 839-852. https://doi.org/10.3390/ijerph1505 0839 